membership. Referring to the need, already emphasized in the Council's report, for a much greater degree of financial support from industry and commerce if the Institute is to become self-supporting within a reasonable period, Sir Charles said that a new campaign for corporate subscribers is to be started in the autumn.

\section{Mining and Metallurgy Abstracts}

THE science and art of metalliferous mining are practised in every part of the globe, and, because no two deposits are exactly alike, the annual output of scientific and practical papers in many countries and different languages is so great that no mining engineer, wishing to keep up to date in current practice, can possibly do so. When to this are added the important ancillary professions such as extraction metallurgy, mineral concentration or 'dressing', applied geology, mechanical and electrical engineer. ing applied to mining, the river of information flowing from the mines is in a perpetual spate. The survey of world literature on mining (excluding coal) and allied subjects (classified according to the Universal Decimal Classification), which is published monthly by the Institution of Mining and Metallurgy, Salisbury House, Finsbury Circus, London, E.C.2, meets a need long felt by members of the allied professions which it serves. The first series, published in the July 1950 issue of the Bulletin of the Institution, contains nearly two hundred abstracts, the average length of each one being of the order of a hundred. words. When it is remembered that mining is frequently practised in districts far from a library, the value of these abstracts to the manager of a lonely mine becomes apparent. Not only are they useful to the individual in isolated mines; but they also fill a want long felt by busy engineers in more crowded areas because they will save both time and money spent searching the literature. Particular attention is paid to the application of pure science to mining problems, for exæmple, surface chemistry in flotation processes.

\section{Bibliography of Seismology}

Two further numbers of the "Bibliography of Seismology", published by the Dominion Observatory, Ottawa, continue the very valuable work of keeping seismologists and others interested up to date with world publications on pure and applied seismology and allied subjects (Publications of the Dominion Observatory, Ottawa. 14 : Bibliography of Seismology, No. 4: Items 6858-7003, July to December 1948. By W. G. Milne. Pp. 71-96. No. 5 : Items 7004-7131, January to June 1949. By W. G. Milne. Pp. 97-133. (Ottawa: King's Printer, 1949-1950.) 25 cents each). The evaluation of the seismicity of various regions of the earth and the elucidation of earth structure by means of earthquake waves still form a large proportion of research in pure seismology. The study of microseisms continues its world-wide appeal as instanced by W. M. Jones's paper on New Zealand microseisms (item 7058), Marion H. Gilmore's paper on the relation of microseisms to meteorology (item 7035) and others. The accurate delineation of salt domes is also still an incentive to the seismic prospector (item 7032). Seismological items from the columns of Nature are listed in the bibliography, and Hirosi Kawasumi contributes twenty-four pages of references to papers written in Japan during 1939-47. Some of these have been published; but others, which have been received at the publication offices of various research institutions and societies in Japan, are intended for publication when the opportunity occurs.

\section{Electrical Power-System Network Analyser}

At the Nelson Research Laboratories of the English Electric Co., Stafford, there was placed in operation at the beginning of the year an alternatingcurrent network analyser. The design and extension of electrical power supply networks nowadays often involve the consideration of a number of alternative schemes, each of considerable complexity and requiring for its analysis a large amount of numerical computation. The amount of computation required for the assessment of a group of such alternatives would be prohibitive. The A.c. network analyser or calculating board is, in effect, a very flexible model which can be arranged to represent the generators, loads and inter-connexions of a power system. The calculating board is so arranged that the appropriate circuit elements can be associated quickly and con. veniently to form the required network, and the values of voltage, current and power at various points in the system measured. For the operation of this analyser, a frequency of $500 \mathrm{c}$./s. has been chosen in order to reduce the size of the iron-cored reactors. Twelve generator units, controllable in magnitude and phase, are available, and impedance units cover the range of impedances normally encountered in power systems. In the metering system negative feed-back amplifiers are employed to operate the instruments, so that the connexion of an instrument disturbs the network to only a negligible extent. The normal applications of the analyser will be to studies of load sharing, fault currents and system stability. This installation is an important addition to the resources of the electrical engineering industry in Britain for dealing with power system problems.

\section{Marine Radar in the Port at Baltimore}

IT is reported in the February issue of the Journal of the Franklin Institute $(249,173 ; 1950)$ that a harbour radar system has recently been installed at the Recreation Pier in the port at Baltimore. This is the third major port in the world to be so equipped, the other two being Long Beach, California, and Liverpool. The radar equipment, which comprises a Westinghouse commercial marine radar unit, provides port operators with a $12 \frac{1}{2}$-in. radar chart of harbour shipping movements at ranges from 80 yards to 40 miles. It will be used in a navigational aid research programme designed to assist ships entering and leaving the port of Baltimore in fog and bad weather, to provide continuous observation of harbour shipping, and to give immediate information of the location of shipping casualties in the harbour.

\section{British Scientific Instrument Research Association}

TнE British Scientific Instrument Research Association has recently published an attractive illustrated booklet describing the activities and various departments of the Association. The Association has the honour of being the oldest of the some fifty existing industrial research organisations operating under the rgis of the Department of Scientific and Industrial Research. It was founded in 1918 and is now an integral part of the scientific instrument industry with more than a hundred firms in member. ship with it. Full-page photographs of the individual 